\section{References}

Cornelius, C. E., Mia, A. S., and Rosenfeld, S. (1965). Investigative Urology, $2,453$.

Eddleston, A. L. W. F., et al. (1973). British Medical fournal, 4, 274.

Fletcher, A. P., Neuberger, A., and Ratcliffe, W. A. (1970). Biochemical

Golding, P. L., Smith, M., and Williams, R. (1973). American fournal of Medicine, 55, 772

Marr, A. M. S., Neuberger, A., and Ratcliffe, W. A. (1971). Biochemical fournal, 122, 623

McKenzie, J. K., and McQueen, E. G. (1969). fournal of Clinical Pathology, 22,334 .
Meyer zum Büschenfelde, K. H., and Kössling, F. K. (1972). In Immunology of the Liver, ed. M. Smith and R. Williams, p. 169. London, Heinemann.

Miller, J., et al. (1972). Lancet, 2, 296.

Mitchell, C. G., et al. (1972). Clinical and Experimental Immunology, 11,

Rhodin, J. (1967). In Renal Disease, ed. D. A. K. Black, 2nd edn., p. 58. Oxford, Blackwell.

Smith, M. G. M., et al. (1972). British Medical fournal, 1, 527.

Søborg, M. (1968). Acta Medica Scandinavica, 184, 135.

Søborg, M. (1968). Acta Medica Scandinavica, 184, 135. mm, I., and Horsfall, F. L., jun. (1950). Proceedings of the Society for Experimental Biology and Medicine, 74, 108

Thomson, A. D. T., et al. (1974). Nature. In press.

\title{
Cell-mediated Immunity to Intrinsic Factor in Autoimmune Disorders
}

\author{
D. JAMES, G. ASHERSON, I. CHANARIN, N. COGHILL, S. HAMILTON, R. L. HIMSWORTH, \\ D. WEBSTER
}

British Medical fournal, 1974, 4, 494-496

\begin{abstract}
Summary
Evidence of cell-mediated immunity to gastric intrinsic factor was present in $86 \%$ of patients with pernicious anaemia and in at least $13 \%$ of patients with hyperthyroidism, $21 \%$ of patients with atrophic gastritis, and four out of nine $(46 \%)$ patients with hypogammaglobulinaemia. Controls gave negative results. The four patients with hypogammaglobulinaemia and cellmediated immunity to intrinsic factor had evidence of impaired gastric function.
\end{abstract}

\section{Introduction}

Pernicious anaemia is common in some disorders in which autoantibodies appear. Thus some $10 \%$ of patients with primary hypothyroidism, $2 \%$ of patients with Graves's disease, and about $4 \%$ of insulin-dependent diabetics have pernicious anaemia. Sera from these groups of patients often contain gastric antibodies, particularly parietal-cell antibodies, which are generally demonstrable in about $30 \%$ of such samples. There is also a high incidence of pernicious anaemia among patients with acquired hypogammaglobulinaemia. Intrinsic-factor antibodies are less common in diseases other than pernicious anaemia, but they occur in $2 \%$ of patients with Graves's disease and less frequently in the other groups as well as in relatives of patients with pernicious anaemia.

The association of pernicious anaemia with hypogammaglobulinaemia is particularly interesting because patients with hypogammaglobulinaemia may lack normal B-lymphocyte function responsible for producing humoral antibodies while they often retain $T$ lymphocytes responsible for cell-mediated immunity. This suggests that at least in these patients, and

\footnotetext{
M.R.C. Clinical Research Centre, Northwick Park Hospital, Harrow, Middlesex HA1 3UJ

D. JAMES, B.A., Research Assistant

I. CHANARIN, M.D., F.R.C.PATH., Consultant Haematologist

G. ASHERSON, D.M., F.R.C.P., Consultant Immunologist

D. WEBSTER, M.D., M.R.C.P., Senior Registrar

R. L. HIMSWORTH, M.D., M.R.C.P., Consultant Physician

S. HAMILTON, M.B., M.R.C.P., Registrar

West Middlesex Hospital, Isleworth, Middlesex

N. COGHILL, M.B., F.R.C.P., Consultant Physician
}

probably in other patients, cell-mediated immunity may be more important in producing pernicious anaemia than humoral antibodies. This view is reinforced by the failure to show humoral intrinsic-factor antibody in either the serum or gastric juice of almost one-third of patients with pernicious anaemia.

This study was undertaken to determine the frequency of cell-mediated immunity to intrinsic factor in these susceptible groups and, in the longer term, whether cell-mediated immunity to intrinsic factor would prove a better indication of the risk of the patient developing pernicious anaemia than tests for humoral antibodies.

\section{Patients and Methods}

Observations were made on 51 patients with proven pernicious anaemia, 14 with histologically-proven atrophic gastritis without pernicious anaemia, eight with acquired hypogammaglobulinaemia and one with an isolated IgA deficiency, 24 with insulindependent diabetes, 14 with primary hypothyroidism, 22 with Graves's disease, and eight patients with toxic nodular goitre. Observations were made also on 105 controls, 51 of whom corresponded in sex and age to the pernicious-anaemia group and 54 of whom were matched to patients in the other groups.

Crude hog intrinsic factor (Armour Pharmaceutical Company) was concentrated by the method of Ellenbogen and Highley (1967) so that $1 \mathrm{mg}$ dried powder bound $45 \mathrm{ng}$ vitamin $\mathrm{B}_{12}$.

Human intrinsic factor was contained in gastric juice collected after pentagastrin stimulation. Bile-stained samples were discarded. The gastric juice was concentrated by ultrafiltration through an Amicon filter so that the intrinsic factor content was $600 \mathrm{U} / \mathrm{ml}$. It was used at an intrinsic factor concentration of 150 intrinsic factor $\mathrm{U} / \mathrm{ml}$.

The leucocyte migration inhibition (M.I.F.) test was set up as described by Rose et al. (1969) using disposable migration chambers (Sterilin Ltd.). Leucocytes were harvested from $25 \mathrm{ml}$ of heparinized blood. Tubes were set up in quintuplicate, with control tubes from which antigen was omitted. The fluid in the chamber contained either hog intrinsic factor $(5 \mathrm{mg}$ ) diluted in $1 \mathrm{ml}$ TC-199 (Burroughs Wellcome) followed by the addition of $10 \%$ fetal calf serum (Burroughs Wellcome) or human gastric juice (600 intrinsic factor $\mathrm{U} / \mathrm{ml}$ ) diluted with three parts TC-199 followed by the addition of $10 \%$ fetal calf serum. Intrinsic factor was replaced by additional TC-199 in controls. Migration zones were traced on paper through a photographic enlarger $(\times 15)$ and areas read with a planimeter. Migration zones from the control group were within a range of $80 \%-120 \%$ of the mean value (see fig. 1). Inhibition of migration 
TABLE I-Frequency of Gastric Antibodies in Patients and Controls

\begin{tabular}{|c|c|c|c|c|c|}
\hline \multirow{2}{*}{ Diagnosis } & \multirow{2}{*}{ No. of Patients } & \multicolumn{2}{|c|}{ Sex } & \multirow{2}{*}{$\begin{array}{l}\text { No. (\%) with } \\
\text { Parietal-cell } \\
\text { Antibodies }\end{array}$} & \multirow{2}{*}{$\begin{array}{l}\text { No. (\%) with } \\
\text { Intrinsic-factor } \\
\text { Antibodies }\end{array}$} \\
\hline & & F. & M. & & \\
\hline $\begin{array}{l}\text { Controls } \\
\text { Pernicious anaemia } \\
\text { Hyperthyroidism } \\
\text { Primary hypothyroidism } \\
\text { Diabetes } \\
\text { Atrophic gastritis } \\
\text { Hypogammaglobulinaemia }\end{array}$ & $\begin{array}{r}105 \\
51 \\
30 \\
14 \\
24 \\
14 \\
9\end{array}$ & $\begin{array}{r}75 \\
37 \\
24 \\
13 \\
15 \\
8 \\
3\end{array}$ & $\begin{array}{r}30 \\
14 \\
6 \\
1 \\
9 \\
6 \\
6\end{array}$ & $\begin{aligned} & 6(6) \\
& 34(67) \\
& 3(10) \\
& 5(36) \\
& 4(17) \\
& 7(50) \\
& 0(0)\end{aligned}$ & $\begin{array}{l}\mathbf{0} \\
26 \\
0 \\
0 \\
0 \\
0 \\
0 \\
0\end{array}$ \\
\hline
\end{tabular}

TABLE II-Cell-mediated Immunity to Intrinsic Factor in Patients and Controls

\begin{tabular}{|c|c|c|c|c|c|c|}
\hline \multirow{2}{*}{ Group } & \multirow{2}{*}{ No. Tested } & \multirow{2}{*}{$\begin{array}{l}\text { Positive for } \\
\text { Migration } \\
\text { Inhibition }\end{array}$} & \multirow{2}{*}{ No. Tested } & \multirow{2}{*}{$\begin{array}{c}\text { Positive } \\
\text { for } \\
\text { Transformation }\end{array}$} & \multicolumn{2}{|c|}{ Both Tests Performed } \\
\hline & & & & & No. Tested & No. Positive \\
\hline $\begin{array}{l}\text { Controls } \\
\text { Pernicious anaemia } \\
\text { Hyperthyroidism } \\
\text { Primary hypothyroidism } \\
\text { Diabetes } \\
\text { Atrophic gastritis } \\
\text { Hypogammaglobulinaemia }\end{array}$ & $\begin{array}{r}59 \\
39 \\
28 \\
13 \\
16 \\
14 \\
9\end{array}$ & $\begin{array}{r}0 \\
26 \\
2 \\
0 \\
0 \\
3 \\
2\end{array}$ & $\begin{array}{r}54 \\
52 \\
11 \\
6 \\
13 \\
14 \\
9\end{array}$ & $\begin{array}{r}0 \\
10 \\
2 \\
0 \\
0 \\
0 \\
2\end{array}$ & $\begin{array}{r}35 \\
10 \\
0 \\
5 \\
14 \\
9\end{array}$ & $\begin{array}{r}0 \\
30 \\
4 \\
5 \\
0 \\
3 \\
4\end{array}$ \\
\hline
\end{tabular}

was considered significant when the leucocyte migration in the presence of intrinsic factor was less than $80 \%$ of that of the mean control.

Lymphocyte transformation tests using ${ }^{14} \mathrm{C}$-thymidine were set up as described by Janossy and Greaves (1972). All tests and controls were set up in triplicate. Two million lymphocytes were used in each culture, which each contained $1 \mathrm{ml}$ of a mixture of TC-199 with $5 \%$ fetal calf serum and $0.1 \mathrm{ml}$ of human gastric juice (60 intrinsic factor units). Intrinsic factor was replaced by additional TC-199 in the controls. In this test the controls gave results of up to 3 on the transformation index, and hence only values above 3 was regarded as significant (see fig. 2).

Parietal cell antibodies were measured by a fluorescent method (Taylor et al., 1962), and intrinsic-factor antibodies were measured by the method of Ardeman and Chanarin (1963).

\section{Results}

The presence of parietal-cell and intrinsic-factor antibodies in the various groups is shown in table $I$.

The results indicating cell-mediated immunity to intrinsicfactor are shown in table II. M.I.F. tests were carried out on 59 controls and lymphocyte transformation tests with human gastric juice in 54 controls. All these gave negative results.

Positive M.I.F. test results were obtained in 26 out of 39 pernicious anaemia and positive transformation test results in 10 out of 52 patients (figs. 1 and 2). All three tests (M.I.F. test with human and hog intrinsic factor and transformation test with human intrinsic factor) were carried out in 35 patients and 30 of these gave a positive result with one or more methods.

Lymphocytes from 28 patients with hyperthyroidism were tested by M.I.F. assay, and two were weakly positive. One of these two patients had a toxic nodular goitre and the other had Graves's disease. Two of the 11 patients tested by the lymphocyte transformation test gave positive results. Altogether four out of 30 patients had possible evidence of cell-mediated intrinsic factor immunity.

Three out of 14 patients with atrophic gastritis gave weakly positive results on M.I.F. testing, but transformations were negative.

Four out of the nine patients with acquired hypogammaglobulinaemia gave positive results, two using M.I.F. technique and two with the transformation technique. These four patients all had pentagastrinfast achlorhydria with extremely low intrinsic factor output. Three out of the four had malabsorption of vitamin $B_{12}$ corrected by additional intrinsic factor. None were anaemic and the mean corpuscular volume was either normal or

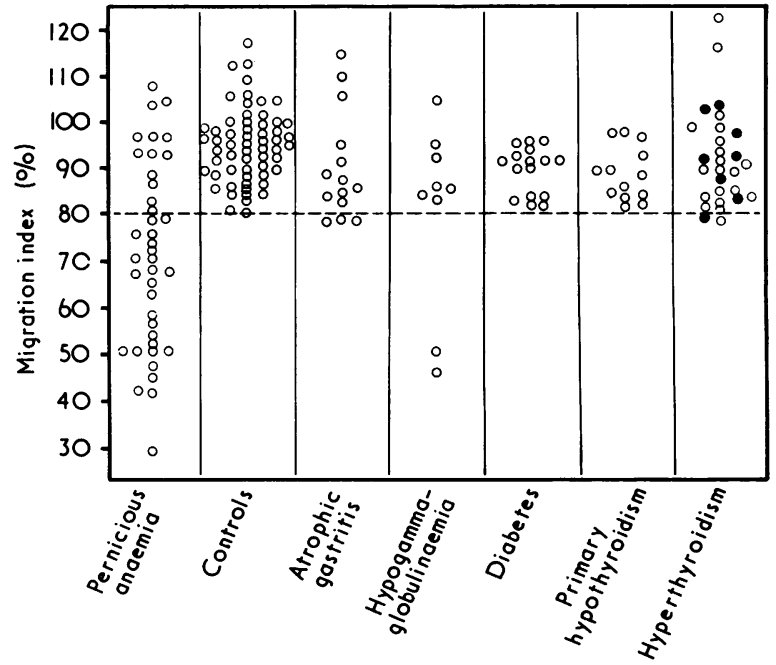

FIG. 1-Results of leucocyte migration test for cell-mediated immunity against intrinsic factor in patients and controls. Values below $80 \%$ were considered positive. In patients with hyperthyroidism $\mathrm{O}=$ Graves's disease, $\mathrm{O}=$ toxic nodular goitre.

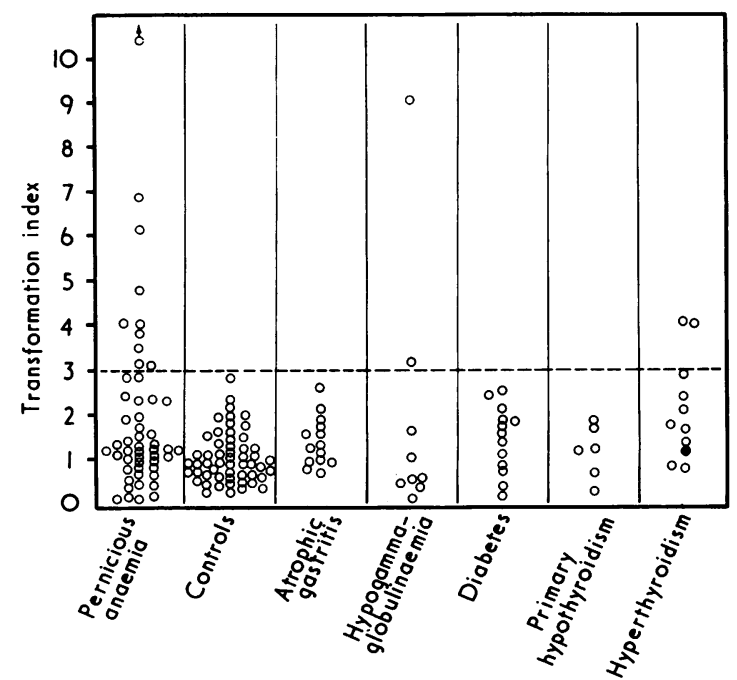

FIG. 2-Transformation of lymphocytes in presence of human gastric juice as test for cell-mediated immunity against intrinsic positive. In patients with hyperthyroidism $\mathrm{O}-$ Graves's disease, positive. In patients with hy
$=$ toxic nodular goitre. 
TABLE III-Details on Four Patients with Cell-mediated Immunity to Intrinsic Factor and Hypogammaglobulinaemia

\begin{tabular}{|c|c|c|c|c|c|c|c|c|c|c|}
\hline \multirow[b]{2}{*}{ Case No. } & \multicolumn{2}{|c|}{ Serum } & \multicolumn{2}{|c|}{ Lymphocytes } & \multirow[b]{2}{*}{$\underset{(\mathrm{g} / 100 \mathrm{ml})}{\mathrm{Hb}}$} & \multirow[b]{2}{*}{$\begin{array}{c}\text { Mean } \\
\text { Corpuscular } \\
\text { Volume } \\
\text { (fl) }\end{array}$} & \multirow[b]{2}{*}{$\begin{array}{l}\text { Intrinsic-factor } \\
\text { Secretion } \\
(\mathrm{U} / \mathrm{hr})\end{array}$} & \multirow[b]{2}{*}{$\begin{array}{c}\text { Serum } \\
\mathbf{B} 1 \mathbf{2} \\
(\mathbf{p g} / \mathrm{ml})\end{array}$} & \multicolumn{2}{|c|}{$\% \mathrm{~B}_{1}$, Absorption } \\
\hline & $\begin{array}{l}\text { Parietal-cell } \\
\text { Antibodies }\end{array}$ & $\begin{array}{l}\text { Intrinsic-factor } \\
\text { Antibodies }\end{array}$ & $\begin{array}{l}\text { IntrinsicFactor } \\
\text { on M.I.F. Test }\end{array}$ & $\begin{array}{l}\text { IntrinsicFactor } \\
\text { on Trans- } \\
\text { tformation Test }\end{array}$ & & & & & $\begin{array}{c}\% B_{12} \\
\begin{array}{c}B_{12} \\
\text { Alone }\end{array}\end{array}$ & $\frac{\text { bsorption }^{*}}{\mathbf{B}_{12}^{+}+}$ \\
\hline $\begin{array}{l}1 \\
2 \\
3 \\
4\end{array}$ & 三 & 三 & $\begin{array}{l} \pm \\
\pm\end{array}$ & $\frac{ \pm}{+}$ & $\begin{array}{l}13.8 \\
14.0 \\
15.6 \\
11.1\end{array}$ & $\begin{array}{l}82 \\
82 \\
78 \\
66\end{array}$ & $\begin{array}{r}141 \\
60 \\
0 \\
82\end{array}$ & $\begin{array}{r}2 \overline{50} \\
75 \\
130\end{array}$ & $\begin{array}{c}0.6 \\
0.7 \\
0.8 \\
\text { Normal } \\
\text { plasma } \\
\text { level }\end{array}$ & $\begin{array}{l}16.4 \\
15.5 \\
18.9 \\
-\end{array}$ \\
\hline Normal Values & - & - & - & - & - & $80-90$ & $\geqslant 2000$ & $\geqslant 170$ & $\geqslant 10$ & $\geqslant 10$ \\
\hline
\end{tabular}

*\% of $1.0 \mu \mathrm{g}$ oral dose of $\mathbf{B}_{1 \mathrm{~s}}$ in 24 -hour urine in Schilling test.

low, due to either iron deficiency or anaemia of infection (table III).

\section{Discussion}

Cell-mediated intrinsic-factor immunity was present in at least $85 \%$ of patients with pernicious anaemia and was absent in 105 controls. A few patients with thyrotoxicosis, atrophic gastritis, or hypogammaglobulinaemia also gave positive results.

The association between pernicious anaemia and hypogammaglobulinaemia was reviewed by Chanarin (1969). Twomey et al. (1970) found that four out of 10 immunoglobulin-deficient patients had pernicious anaemia, and Hughes et al. (1972) found five examples of pernicious anaemia among 12 such patients. Additional patients were described by Douglas et al. (1970), Cowling et al. (1974), and Ginsberg and Mullinax (1970). Gelfands et al. (1972) reported a mother and identical twins all with pernicious anaemia; the twins had immunoglobulin deficiency.

Serum intrinsic factor antibody was present in the case reported by Ginsberg and Mullinax (1970) and in one of the twins reported by Gelfand et al. (1972). This child also gave a positive result on M.I.F. and transformation tests using hog intrinsic factor.

Our results show that out of nine patients with hypogammaglobulinaemia four had cell-mediated immunity against intrinsic factor by conventional tests and in this respect resembled patients with pernicious anaemia. None of these patients had serum antibodies against intrinsic factor or parietal cells. These data support the view that the cell-mediated immunity is the prime factor in bringing about atrophic gastritis in this group. But the low serum gastrin levels found in these patients, together with atrophy of the antrum as well as body of the stomach, suggest that the pathological condition in these patients differs from that seen in cases of pernicious anaemia (Hughes et al., 1972).

Atrophic gastritis of varying degree is a very common lesion of the stomach, which increases in frequency with increasing age. Only very few cases progress to pernicious anaemia and the role of intrinsic factor antibody in this transition is not known. It is of particular interest that evidence of cell-mediated immunity was present in some patients in this group. Only long-term follow up, however, can indicate whether these particular patients will progress eventually to pernicious anaemia. The same arguments apply to the positive results in the other groups.

\section{References}

Ardeman, S., and Chanarin, I. (1963). Lancet, 2, 1350

Chanarin, I. (1969). The Megaloblastic Anaemias, p. 512. Oxford, Blackwell. Cowling, D. C., et al. (1974). Medical fournal of Australia, 1, 15.

Douglas, S. D., et al. (1970). Clinical and Experimental Immunology, 6, 181. Ellenbogen, L., and Highley, D. R. (1967). Fournal of Biological Chemistry, 242, 1004 .

Gelfand, E. W., et al. (1972). Clinical and Experimental Immunology, 11, 187. Ginsberg, A., and Mullinax, F. (1970). American fournal of Medicine, 48, 787. Hughes, W. S., Brooks, F. P., and Conn, H. O. (1972). Annals of Internal Medicine, $77,746$.

Janossy, G., and Greaves, M. F. (1972). Clinical and Experimental Immunology, 10, 525.

Rose, M. S., et al. (1970). Lancet, 2, 9.

Taylor, K. B., et al. (1962). British Medical fournal, 2, 1347.

Twomey, J. J., et al. (1970). Annals of Internal Medicine, 72, 499.

\title{
Double-blind Cross-over Trial of Flurbiprofen and Phenylbutazone in Ankylosing Spondylitis
}

\author{
A. CALIN, R. GRAHAME
}

British Medical fournal, 1974, 4, 496-499

\section{Summary}

A double-blind cross-over study in 35 patients with ankylosing spondylitis was carried out comparing flurbiprofen (150 mg daily) —a new non-steroidal anti-inflammatory agent -with phenylbutazone (300 mg daily) over a four-week

Guy's Arthritis Research Unit, Guy's Hospital Medical School, London SE1 9RT

A. CALIN, M.B., M.R.C.P., Senior Registrar

A. CALIN, M.B., M.R.C.P., Senior Registrar
R. GRAHAME, M.D., M.R.C.P., Consultant Rheumatologist period. Flurbiprofen was well tolerated and shown to have therapeutic efficacy approaching that of phenylbutazone. The results suggest that flurbiprofen may prove a valuable alternative in the treatment of ankylosing spondylitis, and longterm efficacy and tolerance studies are clearly indicated.

\section{Introduction}

Flurbiprofen (B.T.S. 18.322, 2-(fluorobiphenylyl) proponic acid) is a member of the phenylalkanoic acid series. It differs from its predecessors (ibuprofen and ibufenac) in having a biphenyl nucleus but like them possesses antipyretic, anti-inflammatory, and analgesic properties-a triad essential 